\title{
THE ROLE OF MICROBIOTA IN THE DEVELOPMENT OF ALLERGIC DISEASES
}

\section{ROLA MIKROBIOTY W ROZWOJU CHORÓB ALERGICZNYCH}

\author{
Oksana Boyarchuk ${ }^{1(A, D, E)}$, Andrii Chornomydz ${ }^{1(B, C, E, F)}$, Iryna Chornomydz ${ }^{1(A, B, E, F)}$, \\ Halyna Krytska ${ }^{1(B, D, E)}$, Ihor Horishniy ${ }^{1(A, F)}$
}

${ }^{1}$ Ivan Horbachevsky Ternopil State Medical University, Ukraine

Authors' contribution Wkład autorów: A. Study design/planning zaplanowanie badań B. Data collection/entry zebranie danych C. Data analysis/statistics dane - analiza i statystyki D. Data interpretation interpretacja danych E. Preparation of manuscript przygotowanie artykułu F. Literature analysis/search wyszukiwanie i analiza literatury G. Funds collection zebranie funduszy
Tables: 0

Figures: 0

References: 118

Submitted: 2018 Dec 12

Accepted: 2019 Jan 21

\section{Summary}

Scientific progress, industrial development, urbanization, and the "sterile" way of life have a significant negative side, namely, the sustained growth of allergic diseases. The "hygienic theory" is used to explain the unceasing increase in the incidence of allergies in the population. At the same time, an important link in the development of allergic diseases is the microbiological environment and our own microbiota. In our literature review we gathered new data on the pathogenetic relationships between the violation of the quantitative and qualitative composition of our microbiocenosis and the development of allergic diseases. The basic mechanisms by which microbiota influence the development of an allergic process have been established, in particular: influence on T-cell immunity, synthesis of cytokines, etc. In this review, particular attention is paid to factors that lead to microbiocenosis and contribute to the development of allergies. Among them it is worth to highlight inappropriate nutrition, "sterile" style of life, widespread using of antiseptics and antibiotics, etc. Therefore, the most important step in the prevention of allergic diseases is the modification of lifestyle, breastfeeding of children, frequent staying in the open air and contact with nature, rational use of antiseptics and antibiotics.

Keywords: microbiota, microbiome, allergic diseases, hygienic theory

\section{Streszczenie}

Negatywnym aspektem postepu naukowego, rozwoju przemysłowego, urbanizacji i „sterylnego" stylu życia jest stały wzrost zachorowań na choroby alergiczne. Zależność tę wyjaśnia tzw. „teoria higieniczna”, tłumacząca nieprzerwany wzrost liczby alergii wśród społeczeństwa. Równie istotnym czynnikiem w rozwoju chorób alergicznych jest środowisko mikrobiologiczne i nasza własna mikrobiota. W tym artykule staraliśmy się zebrać nowe dane na temat zależności patogenetycznych, pomiędzy naruszeniem ilościowego i jakościowego składu naszej mikrobiocenozy, a rozwojem chorób alergicznych. Podstawowe mechanizmy wpływu mikrobioty oraz procesu powstawania alergii zostały już ustalone, są to przede wszystkim: wpływ komórek T na odporność, synteza cytokin, itp. Obecnie, szczególną uwage poświęca się czynnikom, które prowadzą do powstawania mikrobiocenoz i przyczyniają się do rozwoju alergii. Należą do nich m.in. niewłaściwe odżywianie, „sterylny” styl życia, częste stosowanie środków antyseptycznych i antybiotyków. Z tego powodu najważniejszym krokiem w profilaktyce chorób alergicznych jest zmiana stylu życia, karmienie dzieci piersią, częste przebywanie na świeżym powietrzu, kontakt z naturą i rozsądne stosowanie środków antyseptycznych i antybiotyków.

Słowa kluczowe: mikrobiota, mikrobiom, choroby alergiczne, teoria higieniczna

\section{Introduction}

Allergic diseases form a genetically heterogeneous group of chronic, immune-dependent diseases [1, 2]. Over the last few decades, allergic diseases have become one of the main health problems of the modernized world. The prevalence of atopic dermatitis, food allergy, and asthma has increased dramatically, especially in western societies. It is estimated that between $20 \%$ and $30 \%$ of people living in western countries suffer from at least one form of allergic diseases $[3,4,5,6]$. They are more common among children than adults. Almost 700 million people suffer from allergic respiratory diseases worldwide, namely bronchial asthma and allergic rhinitis [1, 7]. According to recent reports, in the United States there are 15 million children and adults with food allergies

Boyarchuk 0, Chornomydz A, Chornomydz I, Krytska H, Horishniy I. The role of microbiota in the development of allergic diseases. Health Prob Civil. 2019; 13(2): 135-146. https://doi.org/10.5114/hpc.2019.83300

Address for correspondence / Adres korespondencyjny: Iryna Chornomydz, Ivan Horbachevsky Ternopil State Medical University, Maydan Voli, 1, 46001 Ternopil, Ukraine, e-mail: chornomydz@tdmu.edu.ua, phone: +38 0682317989; ORCID: Iryna Chornomydz https://orcid.org/0000-0002-9797-7891

Copyright: (C) Pope John Paul II State School of Higher Education in Biała Podlaska, Oksana Boyarchuk, Andrii Chornomydz, Iryna Chornomydz, Halyna Krytska, Ihor Horishniy. This is an Open Access journal, all articles are distributed under the terms of the Creative Commons Attribution-NonCommercial-ShareAlike 4.0 International (CC BY-NC-SA 4.0) License (http://creativecommons.org/licenses/by-nc-sa/4.0/), allowing third parties to copy and redistribute the material in any medium or format and to remix, transform, and build upon the material, provided the original work is properly cited and states its license. 
$[8,9,10]$. The prevalence of allergic diseases has increased over the last few decades, but at different rates in different regions of the world $[1,11]$. At present, bronchial asthma is considered the most common chronic noninfectious disease among children [11]. In some industrialized countries, the prevalence of asthma is close to $35-40 \%$, while in other regions it is less than $5 \%[1,12,13]$. In addition, the prevalence of asthma is increasing in many low and middle income countries $[1,3,5,6,14,15]$.

It is interesting that the number of children and adults suffering from allergic diseases is almost twice as high in cities as in villages. Many researchers combine this fact with the so-called "hygienic hypothesis," according to which an avalanche-like increase in the incidence of allergic diseases is observed predominantly in highly developed countries, and this is due to a decrease in the effects of antigens found in the environment, the widespread use of antibiotics, the use of chemical additives in production, nutrition, and a very "sterile" lifestyle $[6,16,17]$. Indeed, an increase in the incidence of allergic diseases in industrialized countries has coincided with a widespread distribution of vaccines, the use of antibiotics, a decrease in the size of the family, and the improvement of household amenities $[14,16]$.

The negative impact of allergic diseases is huge both on sick people and their families and society. They negatively affect the quality of life, are a significant psychological burden for the family, and increase comorbidities and the risk of death $[1,3,18,19]$. In addition, the economic burden of these diseases is extremely high $[1,7,20,21]$.

According to the "hygienic theory", the less people are exposed to parasites and microbes, the more this leads to excessive reactivity of the immune system and the development of allergic diseases [17]. Consequently, the impact of microorganisms on the environment and the state of our own microbiome is an important factor that can affect the development of allergic diseases. This is the subject of our review of literature.

\section{Human microbiota}

The term "microbiome" was proposed in 2001 by the Nobel Prize winner Joshua Lederberg to describe the ecosystem of symbiotic and pathogenic microorganisms inhabiting the human body. Lederberg believed that microorganisms in the human body play an important role in health and development of diseases [22, 23, 24].

Recent studies using molecular genetic techniques (sequencing of 16S genes of ribosomal RNA of amplified bacterial nucleic acids derived from feces or biopsy of the intestinal mucosa) demonstrated an incredible complexity of human intestinal microbiota consisting of more than 1000 phylotypes, $80 \%$ of which still have not been cultivated $[25,26]$. Adults contain about 100 billion bacteria only in the intestines, and the microbiome occupies approximately $90 \%$ of the cells in the human body [28]. The human genome consists of about 21,000 genes encoding proteins [29], and microbiota can contain about three million genes [22, 27, 30], which is 100 times greater than the human genome $[24,31,32]$. It is believed that the human microbiota is as unique as the fingerprints of a person [27].

The microbiome (microbiota) of a human is a set of microbiocenoses that colonize all surfaces of the human body, including the skin, respiratory system, gastrointestinal tract and genitourinary system [34, 35].

The microbiome can be considered a "new system organ" since its contribution to human health and disease development was discovered by researchers 20 years ago [22, 25, 33].

The same microorganisms do not occur in all parts of the body. The source of nutrients, humidity conditions, and presence or absence of oxygen affect the nature of microorganisms that can multiply in one or another area. Therefore, the microbiota of the skin, oral cavity, vagina, intestines and others are isolated [27]. The largest part (about 60\%) of the microflora inhabits different regions of the gastrointestinal tract, approximately 15$16 \%$ is accounted for by the oropharynx. The urogenital tract, except the vaginal section, is inhabited rather weakly. Other microorganisms are accounted for by the skin [36]. In the digestive tract, there are more than 500 different types of microorganisms with the biomass of $2.53 \mathrm{~kg}$ [36]. Together, the macroorganism and the microflora constitute a single ecological system that is in a state of homeostasis or eubiosis [36, 37].

The composition and functions of the human intestinal microbiome develop during the first years of life [22]. Despite the widespread belief that the fetal gastrointestinal tract is sterile, recent studies have shown that preterm infants have many contacts with bacteria contained in the amniotic fluid, even if there has been no rupture of membranes or chorioamnionitis before $[41,42]$. At birth, children are in contact with the bacterial flora of the vagina and the mother's anus [41]. Despite this, the microbiota of the child's intestines is finally formed after birth [3, 8, 27, 32, 35].

After birth, the newborn's intestine is temporarily dominated by Enterobacteriaceae and Staphylococcus $[17,43]$. The establishment of stable intestinal microbiota is generally accompanied by two major transitions in childhood. The first transition occurs shortly after birth, during lactation, and leads to predominance of bifidobacteria and some lactic acid bacteria in the intestines $[1,17,44]$. 
The second transition occurs when weaning a child from breastfeeding or with the introduction of solid foods (complementary feeding) [17, 44, 45, 46,47]. With the decrease in the amount of oxygen in the intestines, anaerobes of the Bacteroides and Clostridium genera appear [35]. The Bifidobacterium flora is gradually replaced by the adult-type microorganisms and is mainly represented by bacteria of the Bacteroides, Prevotella, Ruminococcus, Clostridium, and Veillonella genera, which colonize the intestines of the child [49]. In the end, in approximately three years, a typical intestinal microbiota, which is typical for adults $[1,17,31,39,40,42,49]$, is established.

In elderly people, there is another change in the composition and number of microorganisms. There is a significant reduction in the number of Bacteroides and Bifidobacterium; thus, Clostridium, Eubacterium, and Fusobacterium begin to dominate. The result is an increase in the $\mathrm{pH}$ of the intestinal contents to about 7.0-7.5, which may be a cause of diseases of the digestive system in the elderly people [32, 40].

It is important to note that the intestinal microbiotas are distinct among people living in developed and underdeveloped countries, also among urban and rural residents [17].

The microbiota controls numerous metabolic functions, many of which have still not been recognized [34, 50]. Normal microflora performs a number of important functions to ensure the full functioning of the human body, namely: trophic, protective, metabolic, vitamin-forming, endocrine, anti-mutagenic and anti-carcinogenic functions in addition to effects on brain function and behavioral reactions $[16,25,32,36,38,40,52,53,54]$.

Importantly, the immunogenic function of microbiota include the following:

- constant interaction with the immune system of the intestine, regulation of the immune response, and the formation of immunological tolerance;

- secretion of proinflammatory cytokines [16, 36, 39, 52, 53];

- regulate the balance between Th-1 and Th-2 cell activity [22, 56, 57].

Additionally, microbiota is the largest source of antigenic stimuli, which contributes to the development of postnatal immunity due to the maturation of the gastrointestinal-associated lymphoid tissue (GALT) $[3,15,54$, 55].

Consequently, the human microbiome is a complex system that is capable of influencing the human body through communication with many organs and systems, synthesizing a large number of biologically active compounds, and controlling the release of substances with other organs [38].

\section{Relationship of microbiota and allergic processes}

As it has been noted earlier, intestinal microbiota plays a decisive role in the regulation of the immune system [1]. The intestinal epithelium expresses a variety of pathogen recognition receptors, including Toll-like receptors (TLR) and nucleotide-binding oligomerization domain receptors that activate the immune response against pathogenic microorganisms $[1,16]$. In particular, microbiota closely contact the immune system of the intestine through the system of 11 TLRs, each of which recognizes a certain microbial molecular structure [38]. In this case, the immune system is capable of recognizing pathogenic bacteria and intestinal commensals, reacting to pathogens, but at the same time remaining tolerant to commensals. These mechanisms are quite complex and include intestinal epithelial cells, TLRs, dendritic cells, and T-regulatory ( $\mathrm{T}_{\text {reg }}$ ) cells $[1,58]$.

In a healthy state, microbiota have some mucus-like taxons that regulate the production of IL-22, which stimulates the formation of the protective mucous layer by the mucous membrane of the intestines. This barrier is protective and reduces the ability of food allergens to cross the epithelial barrier and enter the microcirculation system. After activation by allergens, epithelial cells secrete cytokines, including TSLP, IL-33 and IL-25, which activate dendritic cells and ILC2 to promote the formation of Th2 cells [59].

T-helper (Th)-2 cells are characterized by the production of IL-4, IL-5, IL-9, IL-13, and the production of allergen-specific IgE that promotes the development and maintenance of an allergic inflammatory process, while Th1-cells produce TNF $\alpha$ and IFN $\gamma$, which promote modulation of cell-mediated immunity [1, 22, 58, 60].

In the classical paradigm, the induction of Th2 cytokine reactions also acts to inhibit Th1 activity (typically via IFN- $\gamma$ ), which helps maintain an allergic phenotype. The stability of this Th1/Th2 balance is also regulated at the gene level through the functions of the transcription factors GATA-3 (Th2) and T-bet (Th1) [3, 31, 39].

Bacterial colonization of the intestine affects the differentiation of precursor T-cells in Treg-cells or different types of Th-cells such as Th1, Th2 and Th17 [61]. Treg-cells suppress the differentiation of precursor T-cells into Th-cells [61] and have various anti-inflammatory effects, including inhibition of inflammatory activity of mast cells, basophils and eosinophils, suppression of IgE synthesis, and IgG4 induction [17, 62].

Numerous studies indicate the importance of the balance of T-helpers (Th1, Th2, Th17, regulatory T-cells) as the main factor in the development of allergic diseases [16, 22]. The physiological microbiota leads to the 
differentiation of Tregs and the release of IL-10, which play a key role in maintaining the Th1/Th2 balance [24]. In this case, when the normal state of the microbiota is violated, Tregs contribute to the promotion of the Th2 lineage [63]. These cells produce cytokines such as IL-4, IL-5, IL-9 and IL-13, which regulate both the activation of B-cells and the synthesis of IgE, as well as the migration of the activated eosinophils, mast cells, and CD4 + T-cells to the site of affection. This leads to the development of allergic diseases $[8,14,36,43,64]$.

A number of intestinal bacteria, including lactic bacteria, bifidobacteria, bacteroides, clostridia and streptococci [65], as well as bacterial metabolites such as butyric acid and propionic acid [15, 66, 67], polysaccharide A (produced by Bacteroides fragilis) are capable of inducing Treg-cells (more precisely, their peripheral type of pTreg) in various experimental models in mice or cell culture $[15,67,68]$. Clinical studies have also shown that probiotic bacteria reduce the formation of Th2 cytokines [69].

The development of allergies in children is associated with a decrease in the level of lactobacilli and bifidobacteria [35]. These bacteria have strong anti-inflammatory properties [70], which are not limited to induction of iTreg IL-10, since the introduction of lactobacilli in mice, carrying defective IL-10 gene still causes inhibition of intestinal inflammation [70]. Their activity is mediated by dendritic cells that secrete IL-10 and TGF- $\beta$, which stimulate the formation of iTreg, and also inhibit Th1, Th2 and Th17-dependent response [35].

Consequently, as evidenced by a large number of studies, there is a link between the intestinal microbiology and the emergence of allergy [5, 17, 34]. It has been shown that in patients suffering from allergic diseases (asthma, atopic dermatitis, food allergy) there is an imbalance in the microbiome: disbacteriosis of respiratory system, skin and digestive system [71].

\section{Intestinal microbiota and allergy}

During the last 15 years, numerous epidemiological studies have been done on the relationship between the microbiotic composition of the intestines and the risk of developing an allergy. The vast majority of these studies indicate that the change in the microbiome in childhood is associated with allergic sensitization and allergic manifestations, especially atopic dermatitis [16, 42].

The first study, devoted to the study of the hypothesis that allergic disease is associated with aberrant microbiota in childhood, was carried out in Sweden in the 1990s [39, 72]. Then, Bjorgsten et al. [72] investigated differences in the microbial composition of the intestine between allergic and non-allergic children, as well as between children living in Sweden and Estonia. After that, a number of epidemiological studies revealed differences in the microbial composition of the intestine between allergic and non-allergic children, although the differences were not always consistent. Indeed, allergic infants were more often colonized by bacteria of the Bacteroides genus and rarely colonized by Acinetobacter and Clostridium bacteria [17].

After that, a large number of studies were conducted. Thus, it has been established that atopic children have lower rates of lactic bacteria, bifidobacteria and bacterial strains [73]. Systematic review of Melli et al. [74] on the role of intestinal microbiota and allergic diseases among children has shown that in children with intestinal allergy, more bacteria such as B. fragilis, E. coli, Clostridium difficile, Bifidobacterium catenulatum and B. bifidum, as well as smaller amounts of $B$. adolescentis, B. bifidum and lactobacilli have beeen found [1]. In their study Ling et al. [75] reported a decrease in Bacteroidetes and an increase in the percentage of Firmicutes (including Clostridiaciae) in 5-month-old children with food allergies [39].

As it has been noted by Kalliomaki et al., in atopic patients' intestines there are more clostridia and less bifidobacteria than in non-atopic people, which has led to a decrease in the ratio between bifidobacteria and clostridia $[15,16,76]$.

The reduced prevalence of bifidobacteria in children with allergies [78] has not been confirmed in all studies $[16,78,79]$. Some authors report that the limited diversity of bifidobacteria is associated with allergy [80], but again it has not been confirmed in other studies $[15,16]$. However, it became clear that the properties of intestinal bifidobacteria primarily depend on strains, especially in immuno-stimulating properties [15, 81]. The change in the species composition of bifidobacteria during allergies is indicated by a large number of researchers [75, 82, 83]. Ouwehand et al. [82] revealed a higher prevalence of Bifidobacterium adolescentis, but the lower one of Bifidobacterium bifidum in children with eczema or atopic eczema compared with healthy children [14].

C. difficile was associated with all atopic symptoms and sensitization [15]. Colonization of faeces at the age of 3 weeks with Clostridium coccoides subcluster XIVa bacteria is described as an early indicator of possible asthma in further life $[15,84]$. Bacteroidaceae is also associated with the development of allergies, although, as for clostridia and bifidobacteria, the results are contradictory [15]. Fujimura et al. indicate that children with a high risk of atopic dermatitis and asthma show a decrease in the relative number of such bacteria as Bifidobacterium, Akkermansia and Faecalibacterium, against the relatively high number of individual fungi such 
as Candida and Rhodotorula [17, 85]. The study of gastrointestinal microbiota in children with food allergy to milk proteins showed more bacteria of the Lactobacillus genus and fewer enterobacteriaceae and bifidobacteria in microbiological cultures, as well as more Clostridium bacteria [71].

However, presently there are no definite bacterial taxons or separate microbiota subgroups that are always associated with allergic diseases [39, 42]. Taking this into account, some studies have shown that early diversity of intestinal microbiotia may be more important than the presence or absence of specific taxons $[86,87,88]$. Several prospective studies have shown that the decline in microbial diversity precedes the development of eczema [86, 88, 89], allergic rhinitis [87], and asthma [39, 86], but not atopic dermatitis [42].

\section{Microbiota of the respiratory tract and allergy}

For many years, there has been an assumption that microflora plays a key role in the development of asthma. The bronchial epithelium has a characteristic microbiome, distinct from healthy people and asthmatics [5]. In studies performed with the help of traditional methods (microbiological cultures), an increased number of atypical bacteria, especially Chlamydophila and Mycoplasma in sputum and fluid after bronchoalveolar lavage in patients with asthma, was detected in comparison to the control group. While studying the lower respiratory tract of patients with asthma, the dominance of proteobacteria, in particular Haemophilus, Moraxella, Neisseria and Streptococcus was found. During active inflammation with asthma, there has been a loss of species diversity of the microflora and an increase in the number of proteobacteria, whereas with hormone resistant asthma, streptococcus and M. catarrhalis have been prevalent in sputum [71].

In addition, the lungs of adults with asthma contain far more bacteria than the lungs of people without asthma. In addition, individuals with severe forms of bronchial asthma have a greater bacterial diversity than patients with moderate asthma $[5,22]$.

\section{Microbiota of skin and allergy}

A characteristic feature of the skin microbiome in patients suffering from atopic dermatitis is the domination of Staphylococcus aureus [37, 73, 90]. In this case, the harmful effects are probably mediated through the development of factors of staphylococcal virulence, including superantigens that stimulate type 2 immune responses and reduce the activity of regulatory T-cells: cytolysins, serine proteases, and lipases that damage the skin barrier. The colonization of $S$. aureus occurs as a result of dysfunction of the skin barrier (for example, reduction of the expression of filaggrin) and increased expression of IL-4 and IL-13. These disorders can occur as a result of genetic and immune reactions caused by allergens or mechanical damage [37].

The aggravation of allergic diseases is characterized by an increased number of pathogenic S. aureus (which leads to a general decrease in microbial diversity). In mice, the $\delta$-toxin secretion of $S$. aureus induces degranulation of mast cells and exacerbates allergic sensitization to the antigen model applied to the skin [17]. In patients with atopic dermatitis, there is a decrease in the microbial diversity of the skin during the exacerbation of the disease $[17,71]$.

\section{Risk factors for the development of allergy, associated with microbiota}

Studies of the links between changes in microbiota composition and a sharp increase in the prevalence of allergy as the "hygiene hypothesis" proposed by D.P. Strachan in 80's, began with clinical observations [5, 91]. Thus, epidemiological studies have shown a link between lower incidence of allergies in many families and children, who are brought up in rural areas, especially in early childhood [73, 92]. There was a reduced risk of allergic diseases in the presence of some individual factors, including the lack of antibiotic therapy in childhood, exclusive breastfeeding during the first 4 months of life, vaginal birth, and the presence of domestic animals [71]. Today, the reduction of microbial effects (and the growth of allergic conditions) is also associated with improved hygiene [3].

Changes in the microbial environment of a person are more often associated with a change in lifestyle during the last 15-20 years $[16,93]$. The increasing prevalence of allergic events, such as asthma or atopic dermatitis, is actually a result of low levels of bacterial exposure during childhood. In some way, children are deprived of immunological stimuli. To a certain extent, this is due to the fact that the inhabitants of the civilized countries spend almost $90 \%$ of their time in a built environment, with about $70 \%$ of the time spent in their apartments or houses and are less outdoors [94]. In fact, it means leaving the environment, in which the microbiome of a person should develop. In particular, it has been shown that in the United States, children who are raised in an internal (home) environment are more likely to suffer from asthma and atopy [15, 95]. 
A particularly interesting topic is the relationship between the increased prevalence of allergic diseases and the increased hygiene of life in the 21st century. The increase of the sterility of our environment, the widespread use of antiseptics and antibiotics (for treatment, at home, consuming with food) and the simultaneous migration of people from villages to cities significantly reduced human contact with the microbiological world. As a result, our immune system in search of new "opponents" began to actively react to substantially harmless particles of food or pollen [37, 53].

Further evidence of the role of microorganisms in the development of allergic diseases stems from the independent study of microbial exposure associated with pet owners. The influence of dogs and, to a lesser extent, cats in childhood, protects against the development of allergic diseases [96]. Fujimura et al. (2010) showed that bacterial communities in household dust from homes, where dogs or cats were present, were significantly richer and more diverse than those, who did not have domestic animals and, according to the author, most of the bacterial taxons from the environment were found in the microbiome of the man's intestinal [15, 97]. This is confirmed by studies, which in particular indicate a reduction in the prevalence of asthma and other allergic diseases in children living on the farm $[39,98,99,100]$. Most researchers attribute this to the fact that children on farms and in the countryside are exposed to more diverse microflora than children, who do not live on farms $[14,22,101]$.

It has also been established that the effect on the skin of gram-negative gamma proteobacteria, common in the soil and on plants such as Acinetobacter, is associated with a decrease in the risk of atopy developing in teenagers [102].

In parallel with this, excessively harsh hygiene practices of a mother and disturbed vaginal flora leads to a weak colonization of the birth canal with lactic bacteria [72]. It should also be noted that the consumption of sterile industrial products by the mother reduces the production of lactic acid by bacteria. Thus, too harsh hygiene during labour, as well as disturbed vaginal flora with a decrease in the proportion of lactic bacteria leads to an increase in the prevalence of atopy in children, as shown by studies made in Sweden and Estonia [72].

As it has been already mentioned, microbial colonization of the intestine usually begins at birth, and this process primarily affects the maternal microbiota of the birth canal and the way of the childbirth (Caesarean section or delivery via natural way). During natural births, newborns are in contact with the bacterial flora of the vagina and the anus of the mother. The sterile environment in which the baby is found during Caesarean section disturbs the colonization described above [41]. After Cesarean section the colonization of the intestine occurs with delay and the composition of microbiota changes [24]. Thus, the microbiome of 1-month-old children, who were born via Cesarean section, contains more Clostridium spp., Klebsiella spp., Enterobacteriaceae, Bacteroides spp., Bifidobacterium spp. and Escherichia coli $[1,6,103,105]$. This effect lasts more than 6 months in newborns and greatly increases the risk of atopy, asthma, and allergic rhinitis $[1,104,105]$. This is confirmed by numerous studies, which report that children born via Caesarean section are more likely to develop asthma and atopy, allergic rhinitis, and food allergies [17, 31, 104, 106].

The method of feeding a newborn child also influences the formation of microflora of the gastrointestinal tract of children. Breastfed infants develop flora, which is dominated by bifidobacteria and lactobacilli that make up 60-91\% of the intestinal microflora [107], while artificial feeding contributes to the development of C. perfringens. This is due to the composition and properties of breast milk, which contains a high concentration of lactose and casein, has a low content of calcium phosphate, and therefore reduces the buffer capacity. It was shown that a decrease in $\mathrm{pH}$ in the intestinal lumen inhibits the growth of bacteroids, clostridia and E. coli, but does not affect bifidobacteria [6]. Bifidobacteria, producing acetic and lactic acids, inhibit the growth of pathogenic strains, in particular E. coli and Clostridium [6, 32].

In addition, breast milk contains many factors that modulate and promote the development of the immune system in childhood, including immunoglobulins such as IgA and IgG, antimicrobial compounds such as lysozyme and lactoferrin, cytokines such as TGF- $\beta$ and interleukin 10 (IL-10), and lymphocytes. In particular, cytokines, such as IL-10 and TGF- $\beta$, in breast milk contribute to the tolerance of the host immune system to the intestinal bacteria and contribute to the development of IL-10 by the child $[17,108]$.

Furthermore, recent studies have shown that breast milk is not sterile. It contains up to 600 different types of bacteria [109]. These are mainly bacteria such as Lactobacillus, Streptococcus, Enterococcus, Lactococcus, and Weissella, as well as some species of Bifidobacterium $[17,110]$. Children who have been breastfed for at least 4 months have a reduced risk of developing asthma [111].

The use of antibiotics at an early age has profound implications for the development of intestinal microbiota. The use of antibiotics in infants changes the composition of intestinal microbiota in relation to a large number of proteobacteria and a low prevalence of actinobacteria populations [112], reduces the overall diversity of microbiota in a child, and promotes the formation of antibiotic resistant strains of bacteria $[17,113]$. 
In addition, it has been noted that taking antibiotics during the first month of life is linked to decreases in the number of anaerobic bacteria (Bifidobacterium, Bacteroides) in relation to enterococci, enterobacteria and coagulase-negative staphylococci $[24,114]$. Clostridium difficile infection is one of the possible complications of antibiotic therapy. Thus, the longer the antibiotic therapy and the wider spectrum of the drug, the greater the risk of infection with $C$. difficile [27].

According to some epidemiological studies, the use of antibiotics at an early age increases the sensitization of the organism [115], increases the risk of developing allergic diseases, such as asthma, atopic dermatitis, and allergic reactions to cow's milk [116]. An alternative system using antibacterial agents can be inhaled antibiotics in inflammatory respiratory diseases $[117,118]$.

\section{Conclusions}

A review of scientific studies indicates the association between the allergic diseases and the state of microbiota. This connection is realized due to the ability of the microflora to affect the activity of the T-cell arm of immunity, the formation of interleukins and other cytokines, interaction with the receptors of the intestinal epithelium, and recognition of antigens. Accordingly, a violation of the quantitative and qualitative composition of microbiota can increase the risk of hypersensitization and allergic diseases. Violation of microbiocenosis can be caused by many factors, in particular: the birth of children via Cesarean section, inappropriate feeding, a "sterile" way of life, wide use of antiseptics and antibiotics, etc. All these factors can lead to the violation of the quantitative and qualitative composition of microbiota and, accordingly, to the increased risk of developing allergic diseases. The most important steps in the prevention of allergic diseases is modification of lifestyle, breastfeeding of children, frequent exposure to the fresh air and contact with nature, and rational use of drugs. In our opinion, these recommendations are basic, without which successful prevention and treatment of allergic diseases is impossible.

\section{References:}

1. Hendaus M, Jomha F, Ehlayel M. Allergic diseases among children: nutritional prevention and intervention. Therapeutics and Clinical Risk Management. 2016; 12: 361-372. https://doi.org/10.2147/TCRM.S98100

2. Shurin MR, Smolkin YS. Immune-mediated diseases: where do we stand?. Adv Exp Med Biol. 2007; 601: 3-12. https://doi.org/10.1007/978-0-387-72005-0_1, https://doi.org/10.1007/978-0-387-72005-0

3. Toh ZQ, Anzela A, Tang MLK, Licciardi PV. Probiotic therapy as a novel approach for allergic disease. Front Pharmacol. 2012; 3: 171. https://doi.org/10.3389/fphar.2012.00171

4. Zuercher AW, Fritsche R, Corthesy B, Mercenier A. Food products and allergy development, prevention and treatment. Curr. Opin. Biotechnol. 2006; 17: 198-203. https://doi.org/10.1016/j.copbio.2006.01.010

5. Bodinier M, Gourbeyre P. [Prebiotics: a strategy to fight allergies?]. La Lettre d'oto-rhino-laryngologie et de chirurgie cervico-faciale. 2012; 331: 27-33 (in French).

6. Roży A, Jaguś P, Chorostowska-Wynimko J. [Probiotics in the prevention and treatment of allergic diseases]. Pneumonol. Alergol. Pol. 2012; 80(1): 65-76 (in Polish).

7. Masoli M, Fabian D, Holt S, Beasley R. The global burden of asthma [Internet]. [cited 2015 Jul 17]. Available from: http://www.ginasthma.org/local/uploads/files/GINABurden Report_1.pdf

8. Wesemann DR, Nagler CR. The microbiome, timing, and barrier function in the context of allergic disease. Immunity. 2016; 44: 728-738. https://doi.org/10.1016/j.immuni.2016.02.002

9. Branum AM, Lukacs SL. Food allergy among U.S. children: trends in prevalence and hospitalizations. NCHS Data Brief. 2008; 10: 1-8.

10. Jackson KD, Howie LD, Akinbami LJ. Trends in allergic conditions among children: United States, 1997-2011. NCHS Data Brief. 2013; 5: 1-8.

11. International Union Against Tuberculosis and Lung Disease. International study of asthma and allergies in childhood. The global asthma report 2011 [Internet]. Paris: International Union Against Tuberculosis and Lung Disease; 2011 [cited 2016 Jan 11]. Available from: http://isaac.auckland.ac.nz/ resources/Global_ Asthma_Report_2011.pdf

12. Soriano JB, Campos HS. Epidemiology of asthma [Internet]. 2012 [cited 2016 Jan 11]. Available from: http://www.sopterj.com.br/profissionais/_revista/2012/n_02/03.pdf

13. Lawson JA, Brozek G, Shpakou A, Fedortsiv O, Vlaski E, Beridze V, et al. An international comparison of asthma, wheeze, and breathing medication use among children. Pub Med Respirat Med. 2017; 133: 22-28. https://doi.org/10.1016/j.rmed.2017.11.001 
14. Kalliomaki M. [The role of the microbiota in allergy]. Ann Nestle (Fr). 2009; 67: 19-26 (in French). https://doi.org/10.1159/000222312

15. Fujimura KE, Lynch SV. Microbiota in allergy and asthma and the emerging relationship with the gut microbiome. Cell Host Microbe. 2015; 17(5): 592-602. https://doi.org/10.1016/j.chom.2015.04.007

16. Waligora-Dupriet AJ, Butel MJ. Microbiota and allergy: from dysbiosis to probiotics [Internet]. 2012 [cited 2012 March 14]. Available from: https://www.intechopen.com/download/pdf/31790

17. Tanaka M, Nakayama J. Development of the gut microbiota in infancy and its impact on health in later life. Allergology International. 2017; 66: 515-522. https://doi.org/10.1016/j.alit.2017.07.010

18. Meltzer EO, Bukstein DA. The economic impact of allergic rhinitis and current guidelines for treatment. Ann Allergy Asthma Immunol. 2011; 106(Suppl. 2): S12-S16. https://doi.org/10.1016/j.anai.2010.10.014

19. Primeau MN, Kagan R, Joseph L, Lim H, Dufresne C, Duffy C, et al. The psychological burden of peanut allergy as perceived by adults with peanut allergy and the parents of peanut-allergic children. Clin. Exp. Allergy. 2000; 30: 1135-1143. https://doi.org/10.1046/j.1365-2222.2000.00889.x

20. Civelek E, Sahiner UM, Yüksel H, Boz AB, Orhan F, Uner A, et al. Prevalence, burden, and risk factors of atopic eczema in schoolchildren aged 10-11 years: a national multicenter study. J Investig Allergol Clin Immunol. $2011 ; 21(4): 270-277$.

21. American Lung Association. Trends in asthma morbidity and mortality [Internet]. 2012 [cited 2015 Jul 17]. Available from: http://www.lung.org/finding-cures/our-research/trend-reports/asthma-trend-report.pdf

22. Riiser A. The human microbiome, asthma, and allergy. Allergy Asthma Clin Immunol. 2015 ; $11: 35$. https://doi.org/10.1186/s13223-015-0102-0

23. Lederberg J, Mccray A. Ome Sweet'Omics - a genealogical treasury of words. Scientist. 2001; $15(7): 8$.

24. Gregorczyk-Maślanka K, Kurzawa R. [Human microbiota. The impact on immune homeostasis - part I]. Alergia Astma Immunologia. 2016; 21(3): 146-150 (in Polish).

25. Tkach S, Tymoshenko 0, Dorofeyeva A. [Involment of gut microboita in the development of obesity and insulin resistance]. Klinichna endokrynolohiya ta endokrynna khirurhiya. 2016; 1(53): 7-16 (in Ukrainian).

26. de Vos WM, de Vos EA. Role of the intestinal microbiome in health and disease: from correlation to causation. Nutr Rev. 2012; 70(Suppl. 1): S45-S56. https://doi.org/10.1111/j.1753-4887.2012.00505.x

27. Cassard AM, Thomas M. [The human microbiota: allies for our health] [Internet]. [cited 2017 Jun 29 ]. Available from: http://www.encyclopedie-environnement.org/app/pdf?idpost=4230\&idauthor=A-9799\&urlimg=\%2Fapp\%2Fuploads\%2F 2017\%2F06\%2FMicrobiote_couverture.jpg (in French).

28. Ley RE, Peterson DA, Gordon JI. Ecological and evolutionary forces shaping microbial diversity in the human intestine. Cell. 2006; 124(4): 837-48. https://doi.org/10.1016/j.cell.2006.02.017

29. Pennisi E. Genomics. ENCODE project writes eulogy for junk DNA. Science. 2012; 337(6099): 1159. https://doi.org/10.1126/science.337.6099.1159

30. Turnbaugh PJ, Ley RE, Hamady M, Fraser-Liggett CM, Knight R, Gordon JI. The human microbiome project. Nature. 2007; 449(7164): 804-810. https://doi.org/10.1038/nature06244

31. West CE, Jenmalm M, Prescott SL. The gut microbiota and its role in the development of allergic disease: a wider perspective. Clinical and Experimental Allergy. 2015; 1(45): 43-53. https://doi.org/10.1111/cea.12332

32. Pokrzywnicka P, Gumprecht J. [Intestinal microbiota and its relationship with diabetes and obesity]. Clin Diabetol. 2016; 5(5): 164-172 (in Polish). https://doi.org/10.5603/DK.2016.0029

33. Plotnikoff GA, Riley D. The human microbiome. Glob Adv Health Med. 2014; 3(3): 4-5. https://doi.org/10.7453/gahmj.2014.023

34. Shyrobokov VP, Yankovsky DS, Dyment HS. [Human microbiom and modern methods of its sanitation]. Infectious Diseases (Ukraine). 2014; 2: 64-69 (in Ukrainian).

35. Strzępa A, Szczepanik M. [Influence of natural gut flora on immune response]. Postepy Hig Med Dosw (online). 2013; 67: 908-920 (in Polish). https://doi.org/10.5604/17322693.1064563

36. Zaykov SV. [Intestines microbiocenosis disorders: is probiotics always required?]. Ratsionalnaya farmakoterapiya. 2008: 2(7): 1-6 (in Russian).

37. Huang YJ, Marsland BJ, Bunyavanich S, O'mahony L, Leung DY, Muraro A, et al. The microbiome in allergic disease: current understanding and future opportunities - 2017. PRACTALL document of the American Academy of Allergy, Asthma \& Immunology and the European Academy of Allergy and Clinical Immunology. Journal of Allergy and Clinical Immunology. 2017; 139(4): 1099-1110. https://doi.org/10.1016/j.jaci.2017.02.007

38. Lapshin O, Odinets M. Intestinal microflora: health effects. Medicine of Ukraine. 2014; (7-8): $183-184$.

39. Bridgman SL, Kozyrskyj AL, Scott JA, Becker AB, Azad MB. Gut microbiota and allergic disease in children. Ann Allergy Asthma Immunol. 2016; 116(2): 99-105. https://doi.org/10.1016/j.anai.2015.10.001 
40. Barczyńska R, Śliżewska K, Libudzisz Z, Litwin M. [The role of intestinal microorganisms to maintain a healthy body weight]. Standardy medyczne/Pediatria. 2013; 1: 55-62 (in Polish).

41. Sharma R, Young C, Mshvildadze M, Neu J. [Intestinal microbiota: does it play a role in diseases of the neonate?]. Pediatria po Dyplomie. 2010; 14(1): 70-87 (in Polish).

42. Penders J, Gerhold K, Thijs C, Zimmermann K, Wahn U, Lau S, et al. New insights into the hygiene hypothesis in allergic diseases. Gut Microbes. 2014; 5(2): 239-244. https://doi.org/10.4161/gmic.27905

43. Matsuki T, Yahagi K, Mori H, Matsumoto H, Hara T, Tajima S, et al. A key genetic factor for fucosyllactose utilization affects infant gut microbiota development. Nat Commun. 2016; 7: 11939. https://doi.org/10.1038/ncomms11939

44. Mitsuoka T. Development of functional foods. Biosci Microbiota Food Health. 2014; 33: 117-28. https://doi.org/10.12938/bmfh.33.117

45. Bergstrom A, Skov TH, Bahl MI, Roager HM, Christensen LB, Ejlerskov KT, et al. Establishment of intestinal microbiota during early life: a longitudinal, explorative study of a large cohort of Danish infants. Appl Environ Microbiol. 2014; 80: 2889-900. https://doi.org/10.1128/AEM.00342-14

46. Backhed F, Roswall J, Peng Y, Feng Q, Jia H, Kovatcheva-Datchary P, et al. Dynamics and stabilization of the human gut microbiome during the first year of life. Cell Host Microbe. 2015; 17: 690-703. https://doi.org/10.1016/j.chom.2015.04.004, https://doi.org/10.1016/j.chom.2015.05.012

47. Dogra S, Sakwinska O, Soh SE, Ngom-Bru C, Brück WM, Berger B, et al. Rate of establishing the gut microbiota in infancy has consequences for future health. Gut Microbes. 2015; 6: 321-5.

https://doi.org/10.1080/19490976.2015.1078051

48. Valles Y, Artacho A, Pascual-García A, Ferrús ML, Gosalbes MJ, Abellan JJ, et al. Microbial succession in the gut: directional trends of taxonomic and functional change in a birth cohort of Spanish infants. PLoS Genet. 2014; 10: e1004406. https://doi.org/10.1371/journal.pgen.1004406

49. Yatsunenko T, Rey FE, Manary MJ, Trehan I, Dominguez-Bello MG, Contreras M, et al. Human gut microbiome viewed across age and geography. Nature. 2012; 486: 222-7. https://doi.org/10.1038/nature11053

50. Bengmark S. Gut microbiota, immune development and function. Pharmacol. Res. 2012; 7: 1023-1029.

51. Bobyr VV, Ponyatovsky VA, Djugikowa EM, Shyrobokov VP. [Intestinal virome and normal microflora of human: features of interaction]. Annals of Mechnikov Institute. 2015; 2: 25-29 (in Ukrainian).

52. Kolesnikova OV. [The intestinal microbiota and metabolic syndrome: the unifying factors]. Suchasna hastroenterolohiia. 2016; 2(88): 61-70 (in Ukrainian).

53. Szachta P, Gałęcka M. [From gut to allergy. Food allergies] [Internet]. Food forum; 2016 [cited 2016 Jul 19]. Available from: https://instytut-mikroekologii.pl/wp-content/uploads/2016/07/0d-jelita-do-alergii.pdf (in Polish).

54. Khachatrian AP. [The role of gut dysbiosis in the pathogenesis of different chronic conditions] [Internet]. K-effect Sp. z o. o. [cited 2016 Jan 11]. Available from: http://k-effect.pl/pages/artykuly/rola-dysbiozyjelitowej-w-patogenezie-roznych-chorob-przewleklych.php (in Polish).

55. Amdekar S, Dwivedi D, Roy P, Kushwah S, Singh V. Probiotics: multifarious oral vaccine against infectious traumas. FEMS Immunol. Med. Microbiol. 2010; 58: 299-306. https://doi.org/10.1111/j.1574-695X.2009.00630.x

56. McLoughlin RM, Mills KH. Influence of gastrointestinal commensal bacteria on the immune responses that mediate allergy and asthma. J Allergy Clin Immunol. 2011; 127(5): 1097-107. https://doi.org/10.1016/j.jaci.2011.02.012

57. O’Mahony C, Scully P, O’Mahony D, Murphy S, O’Brien F, Lyons A, et al. Commensal-induced regulatory T cells mediate protection against pathogen-stimulated NF-kappaB activation. PLoS Pathog. 2008; 4(8): e1000112. https://doi.org/10.1371/journal.ppat.1000112

58. Di Mauro A, Neu J, Riezzo G, Raimondi F, Martinelli D, Francavilla R, et al. Gastrointestinal function development and microbiota. Ital J Pediatr. 2013; 39: 15. https://doi.org/10.1186/1824-7288-39-15

59. Peterson LW, Artis D. Intestinal epithelial cells: regulators of barrier function and immune homeostasis. Nat. Rev. Immunol. 2014; 14: 141-153. https://doi.org/10.1038/nri3608

60. Mazmanian SK, Liu CH, Tzianabos AO, Kasper DL. An immunomodulatory molecule of symbiotic bacteria directs maturation of the host immune system. Cell. 2005; 122(1): 107-118. https://doi.org/10.1016/j.cell.2005.05.007

61. Romagnani S. Regulation of the T cell response. Clin Exp Allergy. 2006; 36: 1357-66. https://doi.org/10.1111/j.1365-2222.2006.02606.x

62. Akdis M. Healthy immune response to allergens: T regulatory cells and more. Curr Opin Immunol. 2006; 18: 738-44. https://doi.org/10.1016/j.coi.2006.06.003 
63. Noval Rivas M, Burton OT, Wise P, Charbonnier LM, Georgiev P, Oettgen HC, et al. Regulatory T cell reprogramming toward a Th2-cell-like lineage impairs oral tolerance and promotes food allergy. Immunity. 2015; 42: 512-523. https://doi.org/10.1016/j.immuni.2015.02.004

64. Lee JB, Chen CY, Liu B, Mugge L, Angkasekwinai P, Facchinetti V, et al. IL-25 and CD4(+) TH2 cells enhance type 2 innate lymphoid cell-derived IL-13 production, which promotes IgE-mediated experimental food allergy. J. Allergy Clin. Immunol. 2015; S0091-6749(15): 01358-5.

65. Geuking MB, Cahenzli J, Lawson MAE, Ng DCK, Slack E, Hapfelmeier S, et al. Intestinal bacterial colonization induces mutualistic regulatory T cell responses. Immunity. 2011; 34: 794-806.

https://doi.org/10.1016/j.immuni.2011.03.021

66. Furusawa Y, Obata Y, Fukuda S, Endo T, Nakato G, Takahashi D, et al. Commensal microbe-derived butyrate induces the differentiation of colonic regulatory T cells. Nature. 2013; 504: 446-450. https://doi.org/10.1038/nature12721

67. Smith PM, Howitt MR, Panikov N, Michaud M, Gallini CA, Bohlooly YM, et al. The microbial metabolites, short-chain fatty acids, regulate colonic Treg cell homeostasis. Science. 2013; 341: 569-573. https://doi.org/10.1126/science.1241165

68. Josefowicz SZ, Niec RE, Kim HY, Treuting P, Chinen T, Zheng Y, et al. Extrathymically generated regulatory T cells control mucosal TH2 inflammation. Nature. 2012; 482: 395-9. https://doi.org/10.1038/nature10772

69. Ghadimi D, Fölster-Holst R, de Vrese M, Winkler P, Heller KJ, Schrezenmeir J. Effects of probiotic bacteria and their genomic DNA on $\mathrm{T}_{\mathrm{H}} 1 / \mathrm{T}_{\mathrm{H}} 2$-cytokine production by peripheral blood mononuclear cells (PBMCs) of healthy and allergic subjects. Immunobiology. 2008; 213(8): 677-692.

https://doi.org/10.1016/j.imbio.2008.02.001

70. Whary MT, Taylor NS, Feng Y, Ge Z, Muthupalani S, Versalovic J, et al. Lactobacillus reuteri promotes Helicobacter hepaticus-associated typhlocolitis in gnotobiotic B6.129P2-IL-10tm1Cgn (IL-10(-/-)) mice. Immunology. 2011; 133: 165-178. https://doi.org/10.1111/j.1365-2567.2011.03423.x

71. Szczepankiewicz A. [The role of microbiome in allergy]. Alergia. 2017; 1: 5-8 (in Polish).

72. Bjorksten B, Naaber P, Sepp E, Mikelsaar M. The intestinal microflora in allergic Estonian and Swedish 2-year-old children. Clin Exp Allergy. 1999; 29: 342-346. https://doi.org/10.1046/j.1365-2222.1999.00560.x

73. Penders J, Thijs C, van den Brandt PA, Kummeling I, Snijders B, Stelma F, et al. Gut microbiota composition and development of atopic manifestations in infancy: the KOALA birth cohort study. Gut. 2007; 56(5): 661667. https://doi.org/10.1136/gut.2006.100164

74. Melli LC, do Carmo-Rodrigues MS, Araújo-Filho HB, Solé D, de Morais MB. Intestinal microbiota and allergic diseases: a systematic review. Allergol Immunopathol (Madr). 2016; 44(2): 177-88. https://doi.org/10.1016/j.aller.2015.01.013

75. Ling Z, Li Z, Liu X, Cheng Y, Luo Y, Tong X, et al. Altered fecal microbiota composition associated with food allergy in infants. Appl Environ Microbiol. 2014; 80: 2546-2554. https://doi.org/10.1128/AEM.00003-14

76. Kalliomaki M, Kirjavainen P, Eerola E, Kero P, Salminen S, Isolauri E. Distinct patterns of neonatal gut microflora in infants in whom atopy was and was not developing. J Allergy Clin Immunol. 2001; 107: 129134. https://doi.org/10.1067/mai.2001.111237

77. Bjorksten B, Sepp E, Julge K, Voor T, Mikelsaar M. Allergy development and the intestinal microflora during the first year of life. J Allergy Clin Immunol. 2001; 108: 516-520. https://doi.org/10.1067/mai.2001.118130

78. Songjinda P, Nakayama J, Tateyama A, Tanaka S, Tsubouchi M, Kiyohara C, et al. Differences in developing intestinal microbiota between allergic and nonallergic infants: a pilot study in Japan. Biosci Biotechnol Biochem. 2007; 71: 2338-2342. https://doi.org/10.1271/bbb.70154

79. Adlerberth I, Strachan DP, Matricardi PM, Ahrne S, Orfei L, Aberg N, et al. Gut microbiota and development of atopic eczema in 3 European birth cohorts. J Allergy Clin Immunol. 2007; 120: 343-350. https://doi.org/10.1016/j.jaci.2007.05.018

80. Stsepetova J, Sepp E, Julge K, Vaughan E, Mikelsaar M, De Vos WM. Molecularly assessed shifts of Bifidobacterium ssp. and less diverse microbial communities are characteristic of 5-year-old allergic children. FEMS Immunol MedMicrobiol. 2007; 51: 260-269. https://doi.org/10.1111/j.1574-695X.2007.00306.x

81. Matto J, Malinen E, Suihko ML, Alander M, Palva A, Saarela M. Genetic heterogeneity and functional properties of intestinal bifidobacteria. J Appl Microbiol. 2004; 97: 459-470. https://doi.org/10.1111/j.1365-2672.2004.02340.x

82. Ouwehand AC, Isolauri E, He F, Hashimoto H, Benno Y, Salminen S. Differences in Bifidobacterium flora composition in allergic and healthy infants. J Allergy Clin Immunol. 2001; 108: 144-145.

https://doi.org/10.1067/mai.2001.115754 
83. Watanabe S, Narisawa Y, Arase S, Okamatsu H, Ikenaga T, Tajiri Y, et al. Differences in fecal microflora between patients with atopic dermatitis and healthy control subjects. J Allergy Clin Immunol. 2003; 111: 587-591. https://doi.org/10.1067/mai.2003.105

84. Vael C, Vanheirstraeten L, Desager KN, Goossens H. Denaturing gradient gel electrophoresis of neonatal intestinal microbiota in relation to the development of asthma. BMC Microbiol. 2011; $11: 68$. https://doi.org/10.1186/1471-2180-11-68

85. Fujimura KE, Sitarik AR, Havstad S, Lin DL, Levan S, Fadrosh D, et al. Neonatal gut microbiota associates with childhood multisensitized atopy and T cell differentiation. Nat Med. 2016; 22: $1187-91$. https://doi.org/10.1038/nm.4176

86. Abrahamsson TR, Jakobsson HE, Andersson AF, Björkstén B, Engstrand L, Jenmalm MC. Low diversity of the gut microbiota in infants with atopic eczema. J Allergy Clin Immunol. 2012; 129: 434-440. https://doi.org/10.1016/j.jaci.2011.10.025

87. Bisgaard H, Li N, Bonnelykke K, Chawes BL, Skov T, Paludan-Müller G, et al. Reduced diversity of the intestinal microbiota during infancy is associated with increased risk of allergic disease at school age. J Allergy Clin Immunol. 2011; 128: 646-652. https://doi.org/10.1016/j.jaci.2011.04.060

88. Ismail IH, Oppedisano F, Joseph SJ, Boyle RJ, Licciardi PV, Robins-Browne RM, et al. Reduced gut microbial diversity in early life is associated with later development of eczema but not atopy in high-risk infants. Pediatr Allergy Immunol. 2012; 23: 674-681. https://doi.org/10.1111/j.1399-3038.2012.01328.x

89. Forno E, Onderdonk AB, McCracken J, Litonjua AA, Laskey D, Delaney ML, et al. Diversity of the gut microbiota and eczema in early life. Clin Mol Allergy. 2008; 6:11. https://doi.org/10.1186/1476-7961-6-11

90. Jones AL, Curran-Everett D, Leung DYM. Food allergy is associated with Staphylococcus aureus colonization in children with atopic dermatitis. J Allergy Clin Immunol. 2016; 137: 1247-8. https://doi.org/10.1016/j.jaci.2015.12.731

91. Strachan DP. Hay fever, hygiene, and household size. BMJ. 1989; 299(6710): 1259-60. https://doi.org/10.1136/bmj.299.6710.1259

92. Maksimova OV, Gervazieva VB,ZverevVV. [Intestine microbiota and allergic diseases]. Zhurnal Mikrobiologii, Epidemiologii, i Immunobiologii. 2014; (3): 49-60 (in Russian).

93. Campeotto F, Waligora-Dupriet AJ, Doucet-Populaire F, Kalach N, Dupont C, Butel MJ. [Establishment of the intestinal microflora in neonates]. Gastroenterol Clin Biol. 2007; 31: 533-542 (in French). https://doi.org/10.1016/S0399-8320(07)89424-3

94. Klepeis NE, Nelson WC, Ott WR, Robinson JP, Tsang AM, Switzer P, et al. The National Human Activity Pattern Survey (NHAPS): a resource for assessing exposure to environmental pollutants. J Expo Anal Environ Epidemiol. 2001; 11: 231-252. https://doi.org/10.1038/sj.jea.7500165

95. Crain EF, Weiss KB, Bijur PE, Hersh M, Westbrook L, Stein RE. An estimate of the prevalence of asthma and wheezing among inner-city children. Pediatrics. 1994; 94: 356-362.

96. Ownby DR, Johnson CC, Peterson EL. Exposure to dogs and cats in the first year of life and risk of allergic sensitization at 6 to 7 years of age. J Am Med Assoc. 2002; 288: 963-972. https://doi.org/10.1001/jama.288.8.963

97. Fujimura KE, Johnson CC, Ownby DR, Cox MJ, Brodie EL, Havstad SL, et al. Man's best friend? The effect of pet ownership on house dust microbial communities. J Allergy Clin Immunol. 2010; 126: 410-412. https://doi.org/10.1016/j.jaci.2010.05.042

98. Muraro A, Halken S, Arshad SH, Beyer K, Dubois AE, Du Toit G, et al. EAACI food allergy and anaphylaxis guidelines. Primary prevention of food allergy. Allergy. 2014; 69: 590-601. https://doi.org/10.1111/all.12398

99. Riedler J, Braun-Fahrlander C, Eder W, Schreuer M, Waser M, Maisch S, et al. Exposure to farming in early life and development of asthma and allergy: a cross-sectional survey. Lancet. 2001; 358: 1129-1133. https://doi.org/10.1016/S0140-6736(01)06252-3

100. Ege MJ, Frei R, Bieli C, Schram-Bijkerk D, Waser M, Benz MR, et al. Not all farming environments protect against the development of asthma and wheeze in children. J Allergy Clin Immunol. 2007; 119: 1140-1147. https://doi.org/10.1016/j.jaci.2007.01.037

101. Von Ehrenstein OS, Von Mutius E, Illi S, Baumann L, Bohm O, von Kries R. Reduced risk of hay fever and asthma among children of farmers. Clin Exp Allergy J Br Soc Allergy Clin Immunol. 2000; 30(2): 187-193. https://doi.org/10.1046/j.1365-2222.2000.00801.x

102. Hogenkamp A, Knippels LM, Garssen J, van Esch BC. Supplementation of mice with specific nondigestible oligosaccharides during pregnancy or lactation leads to diminished sensitization and allergy in the female offspring. J Nutr. 2015; 145: 996-1002. https://doi.org/10.3945/jn.115.210401, https://doi.org/10.3945/jn.114.197707 
103. Azad MB, Konya T, Maughan H, Guttman DS, Field CJ, Chari RS, et al. Gut microbiota of healthy Canadian infants: profiles by mode of delivery and infant diet at 4 months. CMAJ. 2013; 185(5): 385-394. https://doi.org/10.1503/cmaj.121189

104. Grönlund MM, Lehtonen OP, Eerola E, Kero P. Fecal microflora in healthy infants born by different methods of delivery: permanent changes in intestinal flora after cesarean delivery. J Pediatr Gastroenterol Nutr. 1999; 28(1): 19-25. https://doi.org/10.1097/00005176-199901000-00007

105. Kolokotroni O, Middleton N, Gavatha M, Lamnisos D, Priftis KN, Yiallouros PK. Asthma and atopy in children born by caesarean section: effect modification by family history of allergies - a population based crosssectional study. BMC Pediatr. 2012; 12: 179. https://doi.org/10.1186/1471-2431-12-179

106. Koplin J, Allen K, Gurrin L, Osborne N, Tang ML, Dharmage S. Is caesarean delivery associated with sensitization to food allergens and IgE-mediated food allergy: a systematic review. Pediatric Allergy Immunol Off Publ Eur Soc Pediatric Allergy Immunol. 2008; 19(8): 682-687. https://doi.org/10.1111/j.1399-3038.2008.00731.x

107. Cinquin C. [Development and validation of a new model of in vitro colonic fermentation with immobilized cells]. Québec: Thèse de recherche; 2005 (in French).

108. Levast B, Li Z, Madrenas J. The role of IL-10 in microbiome-associated immune modulation and disease tolerance. Cytokine. 2015; 75: 291-301. https://doi.org/10.1016/j.cyto.2014.11.027

109. Jeurink PV, van Bergenhenegouwen J, Jimenez E, Knippels LMJ, Fernandez L, Garssen J, et al. Human milk: a source of more life than we imagine. Benef Microbes. 2013; 4: 17-30. https://doi.org/10.3920/BM2012.0040

110. Jost T, Lacroix C, Braegger C, Chassard C. Assessment of bacterial diversity in breast milk using culturedependent and culture-independent approaches. Br J Nutr. 2013; 110: 1253-1262. https://doi.org/10.1017/S0007114513000597

111. Kull I, Melen E, Alm J, Hallberg J, Svartengren M, van Hage M, et al. Breast-feeding in relation to asthma, lung function, and sensitization in young schoolchildren. J Allergy Clin Immunol. 2010; 125: 1013-1019. https://doi.org/10.1016/j.jaci.2010.01.051

112. Tanaka S, Kobayashi T, Songjinda P, Tateyama A, Tsubouchi M, Kiyohara C, et al. Influence of antibiotic exposure in the early postnatal period on the development of intestinal microbiota. FEMS Immunol Med Microbiol. 2009; 56: 80-87. https://doi.org/10.1111/j.1574-695X.2009.00553.x

113. Greenwood C, Morrow AL, Lagomarcino AJ, Altaye M, Taft DH, Yu Z, et al. Early empiric antibiotic use in preterm infants is associated with lower bacterial diversity and higher relative abundance of enterobacter. J Pediatr. 2014; 165: 23-29. https://doi.org/10.1016/j.jpeds.2014.01.010

114. Penders J, Thijs C, Vink C, Stelma FF, Snijders B, Kummeling I. Factors influencing the composition of the intestinal microbiota in early infancy. Pediatrics. 2006; 118: 511-521. https://doi.org/10.1542/peds.2005-2824

115. Fedonyuk LY, Oleshchuk AM, Sas LM, Boyarchuk OR, Mikolenko AZ, Oryol YuN, et al. Polypragmasy: from paediatrics to geriatrics. Vopr. prakt. pediatr. 2018; 13(1): 77-82.

116. Metsälä J, Lundqvist A, Virta LJ, Kaila M, Gissler M, Virtanen SM. Mother's and offspring's use of antibiotics and infant allergy to cow's milk. Epidemiology. 2013; 24: 303-309. https://doi.org/10.1097/EDE.0b013e31827f520f

117. Boyarchuk O, Krytska H, Chornomydz A, Pelykh V, Chornomydz I, Kosovska T, et al. Perspectives of the inhaled antibiotics usage in pediatrics. Archives of the Balkan Medical Union. 2018; 53(2): 14-22. https://doi.org/10.31688/ABMU.2018.53.2.13

118. Tiddens HAWM, Bos AC, Mouton JW. Inhaled antibiotics: dry or wet?. Eur Respir J. 2014; 44: 1308-1318. https://doi.org/10.1183/09031936.00090314 